\title{
BRD7 wt Allele
}

National Cancer Institute

\section{Source}

National Cancer Institute. BRD7 wt Allele. NCI Thesaurus. Code C157264.

Human BRD7 wild-type allele is located in the vicinity of $16 q 12.1$ and is approximately 55 $\mathrm{kb}$ in length. This allele, which encodes bromodomain-containing protein 7 , is involved in Wnt signaling, p53-mediated G1 to S phase arrest and chromatin remodeling. 